12th LUMEN International Scientific Conference Rethinking Social Action. Core Values in Practice | RSACVP 2019 | 15-17 May 2019 | lasi-

Romania

\title{
Antecedents, Experiences and Entrepreneurial Intentions among Economics Students
}

\author{
Anca Otilia DODESCU, Elena Aurelia BOTEZAT, \\ Ioana Crina POP COHUT, Afrodita BORMA
}

https://doi.org/10.18662/lumproc. 157

How to cite: Dodescu, A.O., Botezat, E.A., Pop Cohut, I.C., \& Borma, A. (2019). Antecedents, Experiences and Entrepreneurial Intentions among Economics Students. In C. Ignatescu (ed.), 12th LUMEN International Scientific Conference Rethinking Social Action. Core Values in Practice, 15-17 May 2019, Iasi Romania (pp. 89-107). Iasi, Romania: LUMEN Proceedings. https://doi.org/10.18662/lumproc.157 



\title{
Antecedents, Experiences and Entrepreneurial Intentions among Economics Students
}

\author{
Anca Otilia DODESCU ${ }^{1}$, Elena Aurelia BOTEZAT², Ioana Crina \\ POP COHUT ${ }^{3}$, Afrodita BORMA ${ }^{4}$
}

Abstract

The paper is part of a larger research aims to increase the impact of entrepreneurship education on students' intentions to become an entrepreneur. Based on the literature in the field of youth entrepreneurship and the theory of planned behaviour, the research considers attitude, subjective norms and perceived behavioral control towards entrepreneurship as students' antecedents of entrepreneurial intentions and exposure to entrepreneurial models, work experience and intuition of trigger events as entrepreneurial experiences. In this context, the paper findings about entrepreneurial intentions of a group of 200 undergraduate students in the first year of study from the Faculty of Economic Sciences, University of Oradea, Romania, before access to formal entrepreneurship education or/and other entrepreneurial education opportunities. The research tests according with theory of planned behavior if there is a positive correlation between students' antecedents, respectivelly experiences and entrepreneurial intentions. Additionally, the research tests whether there is any link between gender, the residential environment (urban, rural), the family origin and the entrepreneurial intentions of the students. The research results allow university to design entrepreneurial educational offer (curricula, programs, extra-curricular activities, practicebased learning etc.) in order to compensate initially perceived lack of support and expose students to experiences that stimulate their entrepreneurial intentions. Also, the research findings provide managerial implications and policy recommendations for increasing the effectiveness of entrepreneurship education and programs. Future research steps seek bypothesis retesting for Economics students after access to entrepreneurship education and address other groups of students from non-economic fields of study where, traditionally, the offer of entrepreneurial education is poor or non-existent.

\footnotetext{
${ }^{1}$ Prof. PhD, Faculty of Economic Sciences, University of Oradea, Oradea, Romania, e-mail: adodescu@,uoradea.ro, Phone: 0040752100800.

2 Prof. PhD, Faculty of Economic Sciences, University of Oradea, Oradea, Romania, e-mail: ebotezat@uoradea.ro, Phone: 0040722260308

3 Senior lecturer, PhD, Faculty of Economic Sciences, University of Oradea, Oradea, Romania, E-mail: ipop@uoradea.ro, Phone: 0040748597932.

${ }^{4}$ Assistant, PhD, Faculty of Economic Sciences, University of Oradea, Oradea, Romania, E-mail: afroditaborma@gmail.com, Phone: 0040734163886.
} 
Anca Otilia DODESCU et al. | Lumen Proceedings 9 | RSACVP2019

Keywords: inclusive entrepreneurship; student's entrepreneurship; entrepreneurship education; entrepreneurial intentions; antecedents; experiences.

\section{Introduction}

In international context, in the last decade, higher education institutions became more aware about their role in entrepreneurship ecosystem and focused on improving their entrepreneurial profile. The most debated dimension of the entrepreneurial profile of universities worldwide is entrepreneurship education, often coupled with research and "third mission" activities (technology transfer and academic entrepreneurship), although institutional context and the broader context of entrepreneurship ecosystem are extremely important to create a favorable framework for entrepreneurial mindset development.

In this context, in Europe, there are major differences between Eastern and Western universities due to their different economic and politic historical context.

Starting from the definition of entrepreneurship as a key competence for life - "an individual's ability to turn ideas into action" [19], European Commission invited all EU Member States to a process of rethinking entrepreneurship education so as to include "at least one practical entrepreneurial experience before leaving compulsory education" [17], and to cover "a broad range of activities across all levels of education - from creativity classes in primary education to Business Master" [18]. A major role in the process of rethinking entrepreneurship education lies with the European universities.

In this respect, the HEInnovate - a joint EC\& OECD initiative - aims to support higher education institutions "to empower students and staff to demonstrate enterprise, innovation and creativity in their teaching, research and third missions" [21]. From HEInnovate perspective, The Netherlands exhibit advanced experience, the higher education sector offering, as shows last country review, excellent examples of what it means to be innovative and entrepreneurial, the current challenge being entrepreneurial mindset development across all subject areas [38].

Looking at East European universities' entrepreneurial profile, education and research are comparatively much better established, while "third mission" activities need further consolidation. For example, in Poland and Hungary, the latest HEInnovate country reviews have identified the need to develop a common understanding of the universities' "third 
mission" and to support institutional capacity-building for enhancing entrepreneurial universities [36, 37].

In the case of Romanian universities, the process of rethinking entrepreneurship education is at an earlier development stage. While The Netherlands and Ireland are concerned to expand entrepreneurship education across all disciplines and areas of study and to increase interdisciplinarity $[35,38]$, in Romania, entrepreneurship is almost absent in non-economic education.

Therefore, the investigation of the relationship between antecedents, experiences and entrepreneurial intentions among Economics students before access to formal entrepreneurship education or/and other entrepreneurial education opportunities is, in our opinion, first step for understanding the impact of entrepreneurship education on students' intentions to become an entrepreneur in Romania.

Our analysis is related with our previous research regarding youth as an inclusive entrepreneurship target group in Romania [7, 8, 13, 14, 15, 16]. Looking at entrepreneurial intentions from local perspective, we found that the role of education is the second most important factor in business creation (after family) for young entrepreneurs in Romania, while the access to finance and bureaucracy followed by lack of experience, the preconceptions of people about the young entrepreneurs and lack of promoting successful entrepreneurship examples are the most important obstacles encountered [15].

Our research findings confirm, as well as many other empirical studies, that in students' perception, "the most important push factor is financial independence" [13], but at the same time highlights a specificity for Romania in case of pull factors: "the limited access to finance is on the same level as the lack of advisory services" [13]. This conclusion led us to further investigation on Economics students which, in the context of Romanian higher education, are almost the only ones who benefit from entrepreneurship courses and, frequently, from entrepreneurial advisory services [7, 13].

The present paper examines the Economics students' antecedents of entrepreneurial intentions and entrepreneurial experiences before access to formal entrepreneurship education or/and other entrepreneurial education opportunities in the case of University of Oradea, Romania.

The structure of the present paper consists of 7 sections. After this Introduction, Section 2 analyzes literature in the field of students' entrepreneurship in order to operationalize the research problem, research hypotheses and to select research methods, Section 3 considers the research 
questions and hypotheses, Section 4 shows the research design used to address the research hypothesis, Section 5 presents the research findings, while Section 6 summarizes and Section 7 concludes the paper.

\section{Problem Statement}

Starting from Casson et al. and Parker approaches [11, 41] and from the OECD inclusive and youth entrepreneurship framework [32, 33, 34], scientific literature considers age and entrepreneurial education as determinants of entrepreneurship, entrepreneurial culture as one of the social and cultural aspects of entrepreneurship and youth as a disadvantaged group compared to entrepreneurship whose exclusion is mainly explained by access to finance.

Derived from the scientific study of youth entrepreneurship, students' entrepreneurship is addressed mainly from two research directions: first, from the perspective of students as "at risk" or the students' exclusion from entrepreneurship and the obstacles encountered; second, from the perspective of entrepreneurial education and its efficiency in transforming students/graduates into entrepreneurs.

Despite studies that demonstrated the impact of higher education on entrepreneurial decision [11, 41], empirical analysis that suggests that the start-up decision is "significantly positively related to the entrepreneurial orientation of the university" [25] and numerous case studies that explore the efficiency of entrepreneurial university supply worldwide, including Romania [3, 26, 42] the mechanism of triggering the students' entrepreneurial intentions has not been fully understood.

Are entrepreneurs born or made on campus? Are there links between gender, the residential environment (urban, rural), the family origin and the entrepreneurial intentions of the students? Are antecedents and experiences before or outside campus relevant for entreprenorial intentions?

The relevance of "prior exposure" [29] to entrepreneurial experiences in the students' entrepreneurial intention have recently prompted the interest of researchers.

Recent case studies highlight differences across nations. For example, Nowinski et al. argues that in case of Visegrad countries, the direct impact of entrepreneurship education was positive and significant" only in Poland [30]. For Poland, Nowinski and Haddoud identified the role models, entrepreneurial attitudes and entrepreneurial self-efficacies as "three dimensions in the process of nurturing entrepreneurial careers" [29]. For Czech Republic, Papadaki, Novak and Dvorsky [40] found a sound 
difference in the entrepreneurial intentions between students without any personal experience in entrepreneurship and who do not have entrepreneurs in their family and those with prior personal entrepreneurial experience or among family members. In Germany, as Krabel's study shows, "work experience prior to studying increases the likelihood of graduates entering self-employment" [25].

Does individual or contextual factors matter in students' entrepreneurial intention? Oftedal, Iakovleva and Foss show that students learn from both educational programmes and context, "would-be student entrepreneurs do not exist separately from their structural context" [31].

An interesting study realized by Bretones and Radrigan [9] by comparing two groups of students from Chile and Spain, aims to discover the attitudinal variables that influence students' entrepreneurial intentions and the influence of cultural context on their entrepreneurial attitude. The study found that the existence of a family tradition of entrepreneurship would be positively related with the students' entrepreneurial intention, students with an individualistic pattern of values would have a higher entrepreneurial intention, cultural context matters so Chilean students showed a greater entrepreneurial intention than Spanish students, students in technological and business related programs had a higher intention of starting a business [9].

The degree program is the most investigated factor in the students' entrepreneurship literature, in relation or not with career anchors, the profession of parents, proactive personality etc. [28, 39] and it is widely recognized that business orientation is significant determinant of students' attitude toward entrepreneurship [26] and entrepreneurial education should be extended outside the business school [43], especially at engineering programs [3,5]. Other investigated factors are gender and residential area, the findings show, as expected, that male and urban students are more inclined to affairs than women [6] or those in rural areas [25].

Regarding teories and models which underlie a research framework for analyzing students' entrepreneurial intentions, we found studies based on the experiential learning theory and on the theory of planned behavior, the entrepreneurial event model, the intentions-based models, the psychosocial cognitive model and integrated versions of these teories and models. Based on the experiential learning theory, Honig and Hopp demonstrated that entrepreneurs who learn through concrete experience "benefit most from informal sources of capital and from their social networks", while abstract conceptualization learners "benefit most from formal sources of capital and from following their developed plans" [22]. Din, Anuar and Usman 
reported findings regarding significant relationship between the effectiveness of entrepreneurship education and risk-thinking, need for achievement and locus of control, whereas business plan and self-efficacy relationship is insignificant [12].

The Ajzen's theory of planned behavior [1,2] better substantiates students' entrepreneurial intention research due to the clear distinction between attitudes, perceived behavioural control and subjective norms. According with Ajzen [1, 2], entrepreneurial intentions of a person are formed through a complex process with some antecedents; attitude, subjective norms and perceived behavioral control towards entrepreneurship as antecedents of entrepreneurial intentions and exposure to entrepreneurial models, work experience and intuition of trigger events as entrepreneurial experiences. From different studies that utilize theory of planned behaviour as theoretical framework, we consider relevant for our research the studies, questionnaires and models implemented and validated by Lorz [27], KimSoon et al. [23] and Asghar et al. [4].

\section{Research Hypothesis}

Based on the Ajzen's theory of planned behavior [1, 2], the present paper examines the Economics students' antecedents of entrepreneurial intentions and entrepreneurial experiences before access to formal entrepreneurship education or/and other entrepreneurial education opportunities in the case of University of Oradea, Romania.

Therefore, we raised two research questions: What is the impact of the antecedents and experiences on students' entrepreneurial intentions? Are there links between gender, the residential environment (urban, rural), the family origin and the entrepreneurial intentions of the students?

Research hypothesis were tested according with theory of planned behavior: 1. There is a positive correlation between students' antecedents and high level of entrepreneurial intentions?, 2. There is a positive correlation between students' experiences and high level of entrepreneurial intentions?

With our present study, we aim to contribute to a more comprehensive understanding of the path through which antecedents and experiences influence students' entrepreneurial intentions and to provide managerial implications and policy recommendations for increasing the effectiveness of entrepreneurship education supply (curricula, programs, extra-curricular activities, practice-based learning etc.) in order to compensate initially perceived lack of support and expose students to experiences that stimulate their entrepreneurial intentions. 
Anca Otilia DODESCU et al. | Lumen Proceedings 9 | RSACVP2019

\section{Research Methods}

The research is based on the study of 202 undergraduate students from the Faculty of Economic Sciences, University of Oradea, Romania, before access to formal entrepreneurship education or/and other entrepreneurial education opportunities. The collection of data took place between February 24 and April 10, 2019. From 290 possible participants, we had 225 respondents $(77,58 \%)$ and validated 202 questionnaires (69,65\%). According to Gorsuch [20], this number of valid questionnaires is relevant.

There were three variables included in this study. The first, Entrepreneurial Antecedents (EA), assesses attitudes, perceived behavioural control and subjective norms. The second variable, Entrepreneurial Experiences (EE), is comprised of three other major components, namely: exposure to entrepreneurial models, work experience and intuition of trigger-events. The third variable we included in our study was Entrepreneurial Intention (EI) and was composed of the two dimensions namely, immediate term intention and future intention.

Our research design followed mainly the research efforts of Lorz [27], Kim-Soon et al. [23] and Asghar et al. [4]. The questionnaire was structured in four parts. The first part included demographical questions where the students were asked to indicate their personal data: age, gender, program of study, general data related to family and prior entrepreneurial education. The second part of the survey included three questions where students were asked about their Entrepreneurial Antecedents (EA) and we utilised 15 items for assessing this first variable. In the third part of our questionnaire we assessed Entrepreneurial Experiences (EE) addressing six questions and utilised 17 items. For the measurement of Entrepreneurial Intention (EI), we utilized 10 items. All items measuring EA, EE and EI were designed to collect data on a 5-point Likert scale.

In order to analyse the data we used SPSS version 17.0. To measure reliability, Cronbach's Alpha was used.

\subsection{Profile of respondents}

The questionnaire was applied to a total of 202 students of the Faculty of Economic Sciences, University of Oradea, gender: female: 79,7\% (161 persons) and male: 20,3\% (41 persons), aged between 18 and 38 years, the majority of whom (97,52\% - 197 persons) are young persons aged between 18-25 years. Most of the respondents come from rural areas $(72,1 \%)$, from families with a low level of income/person between: 801-2000 RON/month $(60,9 \%)$. The majority of the respondents have studied at least one subject 
related to entrepreneurship (64,9\%), have estimated a number of approximately 36 hours of study in the field of entrepreneurship (45\%), and are currently enrolled at university in various programs of study: Accounting (28,7\%), Management (19,8\%), Finance (16,8\%), Marketing (10,9\%), International business administration (13,4\%), Business administration (10,4\%). Students have appreciated their level of knowledge in general entrepreneurship areas at an average level: $46 \%$ for Basics of Business Initiation and Business Plan, 36.6\% for Starting a Business, 35.6\% for Writing a Business Plan.

Of the respondents, $32.6 \%$ have family members who are entrepreneurs, $54.5 \%$ of whom have at least one parent who is an entrepreneur.

Regarding the expectations from entrepreneurship programs, in order of importance - $47 \%$ of them are generally interested in entrepreneurship programs, $21.3 \%$ have entrepreneurial intentions and $20.3 \%$ see themselves as entrepreneurs, therefore these two categories have a specific interest for entrepreneurial programs in order to acquire entrepreneurial skills, while $11.4 \%$ have no specific expectations.

\subsection{Factor analysis and test of variables}

For the three categories of variables described above, reliability was calculated with a Cronbach internal consistency test (This coefficient is used to study the internal consistency of items in a questionnaire). Overall reliability for the total of 42 items was 0,91 , which shows an excellent consistency [10].

To determine whether the variables are representative, two tests were performed: on the one hand, the missing values, the mean sample size, the confidence interval values were verified, and on the other hand, if the variables are normally distributed by asymmetry analysis (Skewness) and flatness (Kurtosis).

For the categories of factors that characterize EA, EE and EI (as abbreviated above), the factors considered to be representative were selected according to the following criteria: Mean - the average sample value of at least 3.3 and a minimum rank 4. Analysing the distribution symmetry, according to Lorz, we considered that a value of 0 for Skewness "would be a perfect normal distribution" [27], seeing that, in practice, a deviation of -2 to +2 is considered acceptable and is assumed to be a normal distribution; respectively, analysing the flatness, ranges from -2 to +2 for Kurtosis acceptable for parametric tests [27].

Thus, of the 15 tested items for $\boldsymbol{E A}, 6$ were validated as representative, as presented in Table 1 EA variables - Descriptive statistics, namely: To be an entrepreneur involves more advantages than disadvantages 
Anca Otilia DODESCU et al. | Lumen Proceedings 9 | RSACVP2019

(EA1); I think the entrepreneur's career is attractive (EA2); I would like to start my own business (EA3); From many variants, I would rather opt to be an entrepreneur (EA4); The level of entrepreneurial skills you have: Leadership and communication skills (EA5); The level of entrepreneurial skills you bave: Relational and teamwork. skills (EA6).

Table 1 EA variables - Descriptive statistics.

\begin{tabular}{lrrrrrr}
\hline $\begin{array}{c}\text { Statistical } \\
\text { description }\end{array}$ & $\boldsymbol{E A 1}$ & $\boldsymbol{E A 2}$ & $\boldsymbol{E A 3}$ & $\boldsymbol{E A 4}$ & $\boldsymbol{E A 5}$ & $\boldsymbol{E A 6}$ \\
\hline Mean & 3,6931 & 4,04455 & 4,6485 & 3,5297 & 3,5396 & 3,8812 \\
Range & 4,00 & 4,000 & 5,00 & 4,00 & 4,00 & 4,00 \\
Skewness &,- 503 &,- 753 &,- 239 &,- 157 &,- 212 &,- 399 \\
Kurtosis &, 605 & 1,350 & 1,965 &,- 068 &,- 435 &, 165 \\
\hline
\end{tabular}

Note: Valid respondents number $\mathrm{N}=202$

In Table 1, the values obtained show a normal distribution, with a Skewness coverage range between -,753 and -,157. Also, the Kurtosis values are within the normal range with values between -,435 and $+1,965$.

For the $\boldsymbol{E} \boldsymbol{E}$ factors category, of the 17 tested, 6 were validated, as presented in Table $2 \boldsymbol{E E}$ variables - Descriptive statistics, namely: What events should bappen in your life to make you become an entrepreneur? The emergence of a successful family entrepreneur (EE1); Existence of Entrepreneurial Learning (EE2); Existence of several courses on entrepreneurship for all fields of study (EE3); According to an increased importance of practical / internship activities in the specialized field (EE4); Creation of at least a permanent information point on the start of a business, allowing easier access to information about starting a business and financing opportunities (EE5); Creating at least a student counselling center to start a business - providing feedback on an idea or business plan, financing opportunities for the business idea (EE6).

Table 2 EE variables - descriptive statistics

\begin{tabular}{lrrrrrr}
\hline $\begin{array}{c}\text { Statistical } \\
\text { description }\end{array}$ & EE1 & EE2 & EE3 & EE4 & EE5 & EE6 \\
\hline Mean & 3,3400 & 3,7400 & 3,8350 & 4,3450 & 4,0050 & 4,3100 \\
Range & 4,00 & 4,00 & 4,00 & 4,00 & 5,00 & 5,00 \\
Skewness &,- 307 &,- 569 &,- 463 & $-1,097$ &,- 622 &,- 622 \\
Kurtosis &,- 482 &, 094 &,- 013 & 1,489 &, 652 &, 652 \\
\hline
\end{tabular}

Note: Valid respondents number $\mathrm{N}=202$ 
In Table 2, the values obtained show a normal distribution, with a Skewness coverage range between $-1,097$ and -,307, flatness falls within normal limits, Kurtosis values have values between -,482 and +1,489.

For the $\boldsymbol{E I}$ factors category, of the 10 tested, 6 were validated, as presented in Table 3 EI variables - Descriptive statistics, namely: I'm ready to become an entrepreneur and to do anything to achieve this (EI1); I'm very interested in being an entrepreneur (EI2); I will make a lot of effort to open and make my own company go (EI3); I'm motivated to open my own company (EI4); Opening my own company when I finish my studies (EI5); I intend to open my business in next 2-5 years (EI6).

Table 3 EI variables - descriptive statistics

\begin{tabular}{lrrrrrr}
\hline $\begin{array}{c}\text { Statistical } \\
\text { description }\end{array}$ & EI1 & EI2 & $\boldsymbol{E I 3}$ & $\boldsymbol{E I 4}$ & $\boldsymbol{E I 5}$ & $\boldsymbol{E I 6}$ \\
\hline Mean & 3,3750 & 3,5700 & 3,7200 & 3,6750 & 3,5600 & 3,5600 \\
Range & 4,00 & 4,00 & 4,00 & 4,00 & 4,00 & 4,00 \\
Skewness &, 003 &,- 264 &,- 339 &,- 029 &,- 121 &,- 013 \\
Kurtosis &,- 185 &,- 100 &,- 563 &,- 706 &,- 708 &,- 796 \\
\hline
\end{tabular}

Note: Valid respondents number $\mathrm{N}=202$

In the Table 3, the values obtained show a normal distribution, with a Skewness coverage range between,- 339 and,+ 003 . Also, the Kurtosis values are within the normal range with values between -,796 and -,100.

\section{Findings}

\subsection{Variable association}

Following the aggregation of the validated variables, by the method of associating the variables, we checked, using Pearson's Chi-square, the degree of association of the aggregate variable Entrepreneurial Antecedents EA (EA1-EA6) and Entrepreneurial Experiences EE (EE1- EE6) and aggregate variable Entrepreneurial Intention EI (EI1EI6) and the significant link between variables was confirmed, a significant influence greater than the statistical threshold of 0.05 (the value Sig $>0.05$ shows a significant correlation between the two evaluated variables). The results obtained can be seen in Table 4 Results obtained by associating variables by Chi-square Test analysis. 
Table 4 Results obtained by associating variables by Chi-square Test analysis.

\begin{tabular}{lccrc}
\hline & Paired Variables & \multicolumn{3}{c}{ Std. } \\
& & Mean & Deviation & Sig. \\
\hline Pair 1 & EA - Aggregate - EI Aggregate &, 31282 &, 86840 &, 000 \\
Pair 2 & EE - Aggregate - EI-Aggregate &, 35325 & 1,02479 &, 000 \\
\hline
\end{tabular}

\subsection{Correlation and regression analysis}

The relationship between Entrepreneurial Antecedents, Entrepreneurial Experience and Entrepreneurial Intention was examined using the Pearson correlation and regression analysis.

Table 5 Correlations between variables describes the correlation results. The results " $\mathrm{R}=0,406$, Sig. $<0,05$ "and" $\mathrm{R}=0,200$, Sig. $<0,05$ " indicate a significant positive value between EA, EE and EI.

Table 5 Correlations between variables

\begin{tabular}{|c|c|c|c|c|}
\hline & & $\begin{array}{c}\text { EA - } \\
\text { Aggregate }\end{array}$ & $\begin{array}{c}\text { EE - } \\
\text { Aggregate }\end{array}$ & $\begin{array}{c}\text { EI- } \\
\text { Aggregat } \\
\mathrm{e}\end{array}$ \\
\hline \multirow[t]{2}{*}{ AA - Aggregate } & $\mathrm{R}$ & &, $119^{*}$ &, $406^{* *}$ \\
\hline & Sig. & &, 046 &, 000 \\
\hline \multirow[t]{2}{*}{ EE - Aggregate } & $\mathrm{R}$ & ,119* & & $200^{* *}$ \\
\hline & Sig. & 046, & & 002, \\
\hline
\end{tabular}

Note: Note: Valid respondents number $\mathrm{N}=202,{ }^{*}$ and ${ }^{* *}$ It means that the correlation is significant (0.05 and 0.01 respectively).

The regression results, presented in Table 6 and Table 7, respectively "R Squared $=0,165$; Beta $=0,388$, Sig. $<0,05$ "and" R Squared $=0,040$; Beta $=0,154$, Sig. $<0,05 "$, indicate a significant positive value for the relationship between EA and EI, on the one hand, and EE and EI, on the other hand. All Beta coefficients were positive and statistically significant. This implies that the higher the entrepreneurial antecedents and the entrepreneurial experiences, the greater the entrepreneurial intention will be. 
Anca Otilia DODESCU et al. | Lumen Proceedings 9 | RSACVP2019

Table 6 Regression results of Entrepreneurial antecedents, Entrepreneurial Experience and Entrepreneurial Intentions

\begin{tabular}{lccccc}
\hline $\begin{array}{c}\text { The main } \\
\text { variables }\end{array}$ & \multicolumn{2}{c}{ Unstandardized } & Standardized & T & Sig. \\
\hline Coefficients & $\mathrm{B}$ & Std. Error & Beta & & \\
\hline $\begin{array}{l}\text { Constant } \\
\text { coefficients }\end{array}$ & 1,417 &, 342 & & 4,138 &, 000 \\
\hline EA - Aggregate &, 400 &, 066 &, 388 & 6,033 &, 000 \\
EA - Aggregate &, 154 &, 064 &, 154 & 2,395 &, 018 \\
\hline
\end{tabular}

Table 7 Results of regression of aggregate variables

\begin{tabular}{ccccc}
\hline & $\mathrm{R}$ & R Squared & Eta & Eta Squared \\
\hline $\begin{array}{c}\text { EA }-\begin{array}{c}\text { Aggregate * EI- } \\
\text { Aggregate }\end{array} \\
\text { EE }-\begin{array}{c}\text { Aggregate * EI- } \\
\text { Aggregate }\end{array}\end{array}$ &, $206^{*}$ &, 165 &, 455 &, 207 \\
\hline
\end{tabular}

Note: $\mathrm{N}=202 *$. Correlation is significant at the 0,01

\subsection{Validation of hypotheses}

After analysing the data obtained, hypothesis $\boldsymbol{H} 1$ is valid $(\mathrm{R}=0,406$, $p<0,05)$. Among the components defining the significant entrepreneurial antecedents as an influence on entrepreneurial intention are: positive attitude towards entrepreneurship, the consideration that an entrepreneurial career is attractive and the importance of gaining entrepreneurial skills, especially communication and relational, as well as teamwork.

Also, hypothesis $\boldsymbol{H} 2$ is valid $(\mathrm{R}=0,200, p<0,05)$. Among the elements associated with entrepreneurial experiences, two events are significant as an influence on the entrepreneurial intention, which should happen in order for the respondent to become an entrepreneur, namely: the existence within the family of a successful entrepreneur and the existence of entrepreneurial programs within the university with entrepreneurial counselling components.

Regarding the students' demographic data (e.g. gender, residential environment, family situation) and entrepreneurial intention (EI) we found positive correlations between belonging to a socially vulnerable group: 
students coming from rural areas, the poor results obtained in the baccalaureate exam and the fact that they are orphans or not $(R=0,236$, $p<0,05)$ and the fact of having an entrepreneur in the family $(\mathrm{R}=0,147$, $p<0,05)$.

\section{Discussions}

The present research connects with the theoretical literature of students' entrepreneurship. The relationship between Entrepreneurial Antecedents (EA), Entrepreneurial Experiences (EE) and Entrepreneurial Intention (EI) in case of Romanian students is almost under-studied.

Our findings reveal, first related to Entrepreneurial Antecedents (EA), that those who have a positive attitude towards entrepreneurship, believe that an entrepreneurial career is attractive and give importance to gaining entrepreneurial skills, especially communication, relational and teamwork, report a higher level of Entrepreneurial Intention (EI). Second, we want to underline, related to Entrepreneurial Experiences (EE), the fact that respondents believe they need tangible proofs (the emergence of a successful entrepreneur in the family) and proofs "at hand" (existence of entrepreneurial programs with entrepreneurial counselling components in the university) that they can see as experiences to trigger their Entrepreneurial Intention. The value of the correlation coefficients $\mathrm{R}=$ 0.406 for Entrepreneurial Antecedents (EA) and $R=0.200$ for Entrepreneurial Experiences (EE) shows that the influence of the Entrepreneurial Antecedents, albeit weak on average, is stronger than that of the Entrepreneurial Experiences (almost non-existent). This was to be expected, given that respondents are students in the first year of study.

What, in our opinion, represents at this point an important result of our research is that, on the basis of the results obtained, we can state that university entrepreneurial programs will have to be designed in such a way as to develop the formation of favourable attitudes towards entrepreneurship, to include modules on entrepreneurial careers and to ensure that students gain communication, relational and teamwork skills. In addition, the inclusion of the entrepreneurial counselling component appears to be a top necessity for any entrepreneurial program. Also, based on the results of our study, we are recommending the stimulation of students who come from rural areas even if they achieved a lower average score at the secondary school leaving exam (Baccalaureate exam), since they have more pronounced entrepreneurial intentions, perhaps due to the desire to overcome their social condition. 
Of course, our research has limits. Firstly, the study was conducted only among the students in the first year. Secondly, they belong exclusively to the field of economic sciences. Future research steps seek hypothesis retesting for Economics students after access to entrepreneurship education and address other groups of students from non-economic fields of study where, traditionally, the offer of entrepreneurial education is poor or non-existent. At the same time, we aim to refine the research in the sense of an in-depth analysis of the entrepreneurial antecedents and entrepreneurial experiences based on the theory of planned behavior components. Regarding entrepreneurial intentions, the stage we reached in our research leads us to the need for researching this variable with other research tools, too, on its two components, namely immediate term-intention and future intention.

\section{Conclusions}

Through this research we have proposed, on the one hand, to empirically investigate the relationship between students' antecedents and entrepreneurial intentions. On the other hand, we want to find if there is a positive relationship between students' experiences (i.e. exposure to entrepreneurial models, work experience and intuition of trigger-events) and entrepreneurial intentions.

We assume a positive relationship between students' antecedents and entrepreneurial intentions (H1) and between students' experiences and entrepreneurial intentions (H2). We mention that the relationship between students' antecedents and entrepreneurial intentions is more powerful than the relationship between students' experiences and entrepreneurial intentions. Moreover, we assume a positive relationship between the environment of origin (i.e. rural areas) and students' entrepreneurial intent, which suggests that students who prefer to change their lives seem to be more motivated in the entrepreneurial direction.

Furthermore, as managerial implications and policy recommendations are concerned, our research highlights that Romanian universities have to take into account in order to design entrepreneurial educational offer (curricula, programs, extra-curricular activities, practice-based learning etc.) two essential aspects: to create a favourable attitude towards entrepreneurship and to include personalized counselling of students in any entrepreneurial program, with particular attention to rural students. Even though our respondents are Economics students, research clearly shows that we should not assume the pre-existence of a favourable attitude to entrepreneurship, but make it a zero priority. Our results highlight the fact that the university can compensate the lack of experience outside the 
campus by developing and delivering entrepreneurial courses with an applicative component coupled with personalized professional counselling, guidance and support services, coaching services, etc. Business partnership, including the existence of a tutor for each student outside the university, can add value to the applicative component of entrepreneurial courses. Nevertheless, these aspects require further investigation.

The results of our research may be useful, especially, for East European universities, whose experience is, in many respects, similar to Romanian experience, facing the same challenge of expanding entrepreneurship education from Economics to all areas of study and developing entrepreneurial mindset across all subject areas. In a broader sense, our research results can also be useful in other socio-cultural spaces, from the perspective of joint projects involving countries, universities in different development stages of rethinking entrepreneurship education and allowing comparative analysis, know-how transfer and exchange of good practices in the process of institutional capacity building for enhancing entrepreneurial universities.

\section{References}

[1] Ajzen I. The Theory of Planned Behavior. Organizational Behavior \& Human Decision Processes. 1991; 50(2): 179-211.

[2] Ajzen I. The theory of planned behavior: reactions and reflections. Psychology \& health. 2011; 26(9): 1113-1127.

[3] Alexe CG, Deselnicu DC, Ioanid A, Tiganoaia B, Mustata C. Entrepreneurship education between perceptions and expectations. Case study: University Politehnica of Bucharest. In: Chova LG, Martinez AL, Torres IC, editors, Rethinking Learning in a Connected Age, Proceedings of the 12th International Technology, Education and Development Conference (INTED), 5-7 March 2018, Valencia, Spain. Valencia: IATED; 2018. 791799.

[4] Asghar MZ, Gul F, Hakkarainen PS, Taşdemir MZ. Validating Entrepreneurial Intentions Questionnaire to Assess the Impact of Entrepreneurship Education. Egitim ve Bilim-Education and Science. 2019; 44 (197): 383-399.

[5] Barba-Sanchez V, Atienza-Sahuquillo C. Entrepreneurial intention among engineering students: The role of entrepreneurship education, European Research on Management and Business Economics. 2018; 24 (1): 53-61.

[6] Belas J, Gurova B, Cepel M, Kotaskova A. Relationship of gender to the position of Slovak University students on the socio-economic determinants of the business environment and the development of entrepreneurship. 
Entrepreneurship and Sustainability. 2018; 6(2): 968-978. Available from: https://ideas.repec.org/a/ssi/jouesi/v6y2018i2p968-978.html.

[7] Botezat E, Borza AF. Exploring Entrepreneurial Potential Among Students. The Annals of the University of Oradea. Economic Sciences. 2016; XXV(2): 488-495. Available from:

https://ideas.repec.org/a/ora/journl/v1y2016i2p488-496.html.

[8] Botezat E. Creative Entrepreneurial Culture: An Empirical Study. International Journal of e-Education, e-Business, e-Management and e-Learning. 2012; 2(4). Available from: http://www.ijeeee.org/Papers/139-Z10012.pdf.

[9] Bretones, FD, Radrigan, M. Attitudes to Entrepreneurship: The Case of Chilean and Spanish University Students. CIRIEC - España, Revista de Economía Pública, Social y Cooperativa. 2019; 94: 11-30. Available from: http://dx.doi.org/10.2139/ssrn.3356474.

[10] Campbell-Sills L, Stein MB. Psychometric analysis and refinement of the Connor-Davidson Resilience Scale (CD-RISC): Validation of a 10-item measure of resilience. Journal of Traumatic Stress. 2007; 20: 1019-1028.

[11] Casson M, Yeung B, Basu A, Wadeson N. The Oxford Handbook of Entrepreneurship. Oxford: Oxford University Press; 2006. 511-651.

[12] Din, BH, Anuar, AR, Usman, M. Contribution of Entrepreneurship Education in Enhancing the Entrepreneurial Capacity Building of Youth, Journal of Computational and Theoretical Nanoscience. 2018; 24(5): 3184-3187.

[13] Dodescu A, Pop Cohuț I, Borma A. A local perspective about students' entrepreneurship. Evidence from Romania. Proceedings of the 4th International Scientific - Business Conference LIMEN 2018 - Leadership \& Management: Integrated Politics of Research and Innovations, December 13, 2018, Belgrade, Serbia. Belgrad: Association of Economists and Managers of the Balkans; 2019. 393-404.

[14] Dodescu A, Pop Cohut, I. Inclusive Entrepreneurship in Romania in the Context of European Union: Theoretical Issues and Emerging Challenges. In: Sandu A, Frunza A, Ciulei T, et al., editors. Rethinking Social Action. Core Values, Proceedings of the 6th LUMEN International Conference on Rethinking Social Action Core Values, 16-19 April 2015, Iași, România. Iași: Lumen; 2015. 463-467.

[15] Dodescu A, Pop Cohuț I. Youth Entrepreneurship and Role Models at Local Level. Case Study: Bihor County, Romania. In: Sandu A, Ciulei T, editors. Rethinking Social Action. Core Values in Practice, Proceedings of the 10th LUMEN International Scientific Conference Rethinking Social Action. Core Values in Practice, RSACVP 2018, 20-21 April 2018, Suceava, Romania. Iași: Lumen; 2018. 117-134.

[16] Dodescu A, Pop-Cohuț I, Chirilă L. Do practice stages encourage students in Economics to practice entrepreneurship? PRACTeam project. Procedia Economics and Finance. 2014; 15: 1083-1090. 
[17] European Commission, DG Education and Culture. Rethinking Education: Investing in skills for better socio-economic outcomes. Strasbourg: $\operatorname{COM}(2012) 669$ final; 20.11.2012. Available from: https://ec.europa.eu/digital-single-market/en/news/communicationrethinking-education.

[18] European Commission. Entrepreneurship Education: A road to success. A compilation of evidence on the impact of entrepreneurship education strategies and measures, Luxembourg: Publications Office of the European Union; 2015. Available from:

https://ec.europa.eu/growth/content/entrepreneurship-education-roadsuccess-0 it.

[19] European Parliament. Key competences for lifelong learning.

Recommendation 2006/962/EC of the European Parliament and of the Council of 18 December 2006 on key competences for lifelong learning: OJ L 394; 2006. Available from:

http://europa.eu/legislation_summaries/education training_youth/lifelong_l earning/c11090 en.htm.

[20] Gorsuch RL. Factor Analysis, 2nd ed.; Erlbaum: Hillsdale, NJ, USA, 1983.

[21] HEInnovate website: https://heinnovate.eu/en.

[22] Honig B, Hopp C. Learning orientations and learning dynamics: Understanding heterogeneous approaches and comparative success in nascent entrepreneurship. Journal of Business Research. 2019; 94 41.

[23] Kim-Soon N, Ahmad AR, Ibrahim NN. Theory of Planned Behavior: Undergraduates' Entrepreneurial Motivation and Entrepreneurship Career Intention at a Public University, Journal of Entrepreneurship: Research \& Practice. 2016. Available from:

http://www.ibimapublishing.com/journals/JERP/jerp.html.

[24] Kolosta, S, Flaska, F, Nedelova, G, Kaščáková A, Årethun T, Nesse JG. Factors Influencing Entrepreneurial Intentions of Slovak Youth Growing up in Cities and in Villages. International Journal of Organizational Leadership. 2018; 7 (3): 270-283.

[25] Krabel S. Are entrepreneurs made on campus? The impact of entrepreneurial universities and graduates' human capital on graduates' occupational choice. Journal of International Entrepreneurship. 2018; 16 (4): 456-485.

[26] Leovaridis C, Frunzaru V, Cismaru DM. Entrepreneurial Education in Romanian Universities. In: Chova LG, Martinez AL, Torres IC, editors. Proceedings of the 10th International Technology, Education and Development Conference, INTED 2016, 7-9 March, 2016, Valencia, Spain. Valencia: IATED; 2016. 92-102.

[27] Lorz M. The Impact of Entrepreneurship Education on Entrepreneurial Intention. Dissertation of the University of St. Gallen, School of 
Management, Economics, Law, Social Sciences and International Affairs, Difo Druck GmbH, Bamberg, Germany. 2011. Available from:

https://www1.unisg.ch/www/edis.nsf/SysLkpByIdentifier/3966/\$FILE/dis3 966.pdf.

[28] Morillo BJ, Avila-Rondon M, Alfaro-Pozo R. Analysis of knowledge, perception and assessment of innovation and entrepreneurship competence by bachelor's degree students. In: Chova LG, Martinez AL, Torres IC, editors, Rethinking Learning in a Connected Age, Proceedings of the 12th

International Technology, Education and Development Conference (INTED), 5-7 March 2018, Valencia, Spain. Valencia: IATED; 2018. 3157-3160.

[29] Nowinski W, Haddoud MY. The role of inspiring role models in enhancing entrepreneurial intention. Journal of Business Research. 2019 ; 96: 183-193.

[30] Nowinski, W, Haddoud MY, Lancaric D, Egerová D, Czeglédi C. The impact of entrepreneurship education, entrepreneurial self-efficacy and gender on entrepreneurial intentions of university students in the Visegrad countries. Studies in Higher Education. 2019 ; 44 (2): 361-379.

[31] Oftedal, EM, Iakovleva TA, Foss L. University context matter: An institutional perspective on entrepreneurial intentions of students. Education and Training. 2018; 60 (7-8 Special Issue): 873-890.

[32] Organisation for Economic Co-operation and Development/ The European Union (OECD/EU). The Missing Entrepreneurs 2017: Policies for Inclusive Entrepreneurship. Paris: OECD Publishing; 2017.

[33] Organisation for Economic Co-operation and Development/ The European Commission (OECD/EC). The Missing Entrepreneurs: Policies for Inclusive Entrepreneurship in Europe. Paris: OECD Publishing; 2013.

[34] Organization for Economic Co-operation and Development (OECD). Youth Entrepreneurship, A background paper for the OECD Centre for Entrepreneurship, SMEs and Local Development. Paris: OECD Publishing; 2013.

[35] Organization for Economic Co-operation and Development/ European Union (OECD/EU). Supporting Entrepreneurship and Innovation in Higher Education in Ireland, OECD Skills Studies. Paris/Brussels: OECD Publishing/EU; 2017. Available from: https://doi.org/10.1787/9789264270893-en.

[36] Organization for Economic Co-operation and Development/ European Union (OECD/EU). Supporting Entrepreneurship and Innovation in Higher Education in Hungary, OECD Skills Studies. Paris/Brussels: OECD Publishing/EU; 2017. Available from: https://doi.org/10.1787/9789264273344-en.

[37] Organization for Economic Co-operation and Development/ European Union (OECD/EU). Supporting Entrepreneurship and Innovation in Higher Education in Poland, OECD Skills Studies. Paris/Brussels: OECD 
Publishing/EU; 2017. Available from:

https://doi.org/10.1787/9789264270923-en.

[38] Organization for Economic Co-operation and Development/ The European Union (OECD/EU). Supporting Entrepreneurship and Innovation in Higher Education in The Netherlands, OECD Skills Studies. Paris/Brussels: OECD Publishing/EU; 2018. Available from: https://doi.org/10.1787/9789264292048-en.

[39] Overall J, Gedeon S, Valliere D. What can universities do to promote entrepreneurial intent? An empirical investigation. International Journal of Entrepreneurial Venturing. 2018; 10(3): 312-332.

[40] Papadaki S, Novak P, Dvorsky J. Attitude of university students to entrepreneurship. Economic Annals - XXI. 2017; 166(7-8): 100-104.

[41] Parker SC. The Economics of Entrepreneurship. Cambridge: Cambridge University Press; 2009.

[42] Szabo Z, Marian L. Pedagogical Methods and Models for Entrepreneurship Education in Romania: Case study. In: Fulford H, editor. Proceedings of the 6th European Conference on Innovation and Entrepreneurship, ECIE2011, Aberdeen, Scotland, UK, 15-16 September 2011. Academic Conferences and Publishing International Limited; 2011. 805-811.

[43] Turner T, Gianiodis P. Entrepreneurship Unleashed: Understanding Entrepreneurial Education outside of the Business School. Journal of Small Business Management. 2018; 56(1 Special Issue): 131-149. 